\title{
High Reusability of NiAI LDH/Biochar Composite in the Removal Methylene Blue from Aqueous Solution
}

\author{
Aldes Lesbani ${ }^{12^{*}}$, Neza Rahayu Palapa ${ }^{1}$, Rabellia Juladika Sayeri ${ }^{2}$, \\ Tarmizi Taher ${ }^{3}$, and Nurlisa Hidayati ${ }^{4}$ \\ ${ }^{1}$ Graduate School of Mathematics and Natural Sciences, Faculty of Mathematics and Natural Sciences, Universitas Sriwijaya, \\ Jl. Palembang Prabumulih Km. 32, Ogan Ilir 30662, Indonesia
}

${ }^{2}$ Research Center of Inorganic Materials and Coordination Complexes, Faculty of Mathematics and Natural Sciences, Universitas Sriwijaya, Jl. Palembang Prabumulih Km. 32, Ogan Ilir 30662, Indonesia

${ }^{3}$ Department of Environmental Engineering, Institut Teknologi Sumatera, Jl. Terusan Ryacudu, Way Hui, Kecamatan Jati Agung, Lampung Selatan 35365, Indonesia

${ }^{4}$ Department of Chemistry, Faculty of Mathematics and Natural Sciences, Universitas Sriwijaya, Jl. Palembang Prabumulih Km. 32, Ogan Ilir 30662, Indonesia

\section{* Corresponding author:}

email:aldeslesbani@pps.unsri.ac.id

Received: June 16, 2020

Accepted: January 4, 2021

DOI: $10.22146 / \mathrm{ijc} .56955$

\begin{abstract}
Ni/Al layered double hydroxide was used as a starting material for composite formation with biochar as a matrix. The materials were characterized using X-ray, FTIR, nitrogen adsorption-desorption, thermal, and morphology analyses. The NiAl LDH/Biochar material is then used as an adsorbent of methylene blue from an aqueous solution. The factor that was influencing adsorption such as $\mathrm{pH}$, time, methylene blue concentration, and temperature adsorption was studied systematically. The regeneration of adsorbent was performed to know the stability of NiAl LDH/Biochar under several cycle adsorption processes. The results showed that NiAl LDH/Biochar has a specific diffraction peak at $11.63^{\circ}$ and $22.30^{\circ}$. NiAl LDH/Biochar has more than ten-fold surface area properties $\left(438,942 \mathrm{~m}^{2} / \mathrm{g}\right)$ than biochar $\left(50.936 \mathrm{~m}^{2} / \mathrm{g}\right)$, and Ni/Al layered double hydroxide $\left(92.682 \mathrm{~m}^{2} / \mathrm{g}\right)$. The methylene blue adsorption on NiAl LDH/Biochar follows a pseudo-second-order kinetic adsorption model and classify as physical adsorption. The high reusability properties were found for NiAl LDH/Biochar, which was largely different from biochar and Ni/Al layered double hydroxide.
\end{abstract}

Keywords: Ni/Al; layered double hydroxide; biochar; composite; methylene blue; adsorption; reusability

\section{- INTRODUCTION}

The presence of hazardous dyes in industrial activities is a severe problem for humans and the ecology system [1]. These dyes are toxic, carcinogenic, and mutagenic, thus cause human and environmental health. The dyes are produced from industrial activities such as cosmetics, painting, textile, leather, food, and also drug industries [2-4]. The dyes are challenging to degrade since they are stable structures under oxidation and light [5]. One of the toxic dyes is methylene blue, a methylthioninium chloride compound and classifies as a cationic dye [6]. The structure of methylene blue is shown in Fig. 1. Thus, the removal of methylene blue from wastewater is crucial. Some methods are available to remove methylene blue from an aqueous solution, such as purification, membrane separation, and adsorption [7-9].<smiles>CN(C)c1ccc2nc3ccc(=[N+](C)C)cc-3sc2c1</smiles>

Fig 1. Chemical structure of methylene blue 
Among these methods, adsorption is an appropriate method to remove methylene blue from the aqueous solution. This method was easy to do, simple way, lowcost operation, and fast process [10]. On the other hand, the effectivity of adsorbent in the adsorption process is one factor in getting high adsorption capacity and stability of the material. Numerous adsorbents have been applied to remove methylene blue from an aqueous solution, such as zeolite, bentonite, carbon nanotube, biomass, activated carbon, chitosan, and also layered double hydroxide [11-13].

Layered double hydroxide ( $\mathrm{LDH})$ is an inorganic material that has the general formula $\left[\mathrm{M}^{2+}{ }_{1-\mathrm{x}} \mathrm{M}^{3+}{ }_{\mathrm{x}}(\mathrm{OH})_{2}\right]+$ $\mathrm{xA}_{\mathrm{x}}{ }^{-\mathrm{n}} \mathrm{mH}_{2} \mathrm{O}$, where $\mathrm{M}^{2+}$ is a divalent metal ion, $\mathrm{M}^{3+}$ is a trivalent metal ion, $\mathrm{A}_{\mathrm{x}}{ }^{-\mathrm{n}}$ is an anion with $\mathrm{n}$ valent state, and water of crystallization [14-15]. LDH consists of an anion on the interlayer distance, which can be exchangeable to other anions to get unique properties of $\mathrm{LDH}$. The common anion in $\mathrm{LDH}$ is nitrate, sulfate, hydroxide, chloride, and carbonate [16-18]. The total charge of LDH is positively due to neutralizing negative charge from anion on interlayer space. LDH has wellknown as an adsorbent of dyes due to its high adsorption capacity and high surface area properties.

On the other hand, the use of LDH several times the regeneration process is ineffective due to sprayed and exfoliated LDH structure [19]. Thus modification of LDH for reuse adsorbent aim should be conducted, such as the formation of the composite using matrix/support materials which can reduce the particle size of $\mathrm{LDH}$ to be facile for reuse adsorbent. One of the promising materials as a matrix for $\mathrm{LDH}$ is biochar. Biochar is an organic compound from the pyrolysis of biomass under high temperature [20]. The use of biochar for many applications is reported, such as water treatment, soil improvement materials, and also pharmaceutical applications [21-22]. The composite of LDH-biochar as an adsorbent of many organic and inorganic pollutants has been reported in many publications.

$\mathrm{MgAl}$ and $\mathrm{Mg} / \mathrm{Fe}$-biochar were prepared as adsorbents of phosphate [23]. Phosphate was also successfully removed from an aqueous solution using $\mathrm{Mg} / \mathrm{Al} \mathrm{LDH-biochar} \mathrm{[24].} \mathrm{Biochar} \mathrm{from} \mathrm{date} \mathrm{palm} \mathrm{was}$ used as a matrix for the composite of $\mathrm{MgAl} \mathrm{LDH}$ biochar. This biochar has an adsorption capacity of $302.75 \mathrm{mg} / \mathrm{g}$ at $100 \mathrm{mg} / \mathrm{L}$ in $180 \mathrm{~min}$ adsorption time [25]. $\mathrm{LDH} \mathrm{Mg/Al-biochar} \mathrm{has} \mathrm{been} \mathrm{prepared} \mathrm{to} \mathrm{form} \mathrm{a}$ composite as an adsorbent of methylene blue. This adsorbent can achieve adsorption capacity until $406.47 \mathrm{mg} / \mathrm{g}$ [9]. Lins et al. [26] introducing liquid phase co-precipitation of $\mathrm{Mg}-\mathrm{Al} \mathrm{LDH}$ on a biochar matrix for enhanced phosphate adsorption. Wang et al. [27] reporting high arsenic adsorption onto $\mathrm{Ni}-\mathrm{Fe} \mathrm{LDH}-$ biochar composite. Despite different biochars used, these studies, in general, suggest that selective adsorption of anionic pollutants depends on the type of LDHs used, and the adsorption mechanisms are linked to interlayer spacing and electrical properties of LDHs. All these studies showed that LDH is commonly used to prepare composite using biochar as a matrix.

This study aims to use LDH based nickelaluminum as a starting material to form a composite with biochar as an adsorbent of methylene blue. Formation of $\mathrm{Ni} / \mathrm{Al} \mathrm{LDH} /$ biochar was prepared by mixing the co-precipitation method. The materials were characterized using X-ray, FTIR, BET, thermal, and photo SEM-EDX analyses. The adsorption was studied through the effect of $\mathrm{pH}$ medium, adsorption time, initial concentration of methylene blue, and temperature adsorption. The performance of the adsorbent was investigated through reusability adsorbent several times. Prior to these processes, desorption is conducted to know the suitable solvent to desorb methylene blue on the solid adsorbent.

\section{- EXPERIMENTAL SECTION}

\section{Chemicals and Instrumentation}

Chemicals used in this research were nickel(II) nitrate, aluminum(III) nitrate, sodium hydroxide, and methylene blue. These chemical reagents were used directly from Merck and Sigma-Aldrich without further purification. Biochar based on Indonesian rice husk was obtained from Bukata Organic, Java Island. Water was obtained from Research Center of Inorganic Materials and Complexes FMIPA Universitas Sriwijaya using Purite $^{\circledast}$ water ion exchange purification system. 
Characterization of the material was performed using Xray Rigaku Miniflex-6000. The material was analyzed in the range $5-80^{\circ}$ with scan speed $1 \%$ min. FTIR spectrum was obtained from FTIR Shimadzu Prestige-21. Materials were mixed with $\mathrm{KBr}$ to form a pellet and were scanned at wavenumber $400-4000 \mathrm{~cm}^{-1}$. Nitrogen adsorptiondesorption analysis was conducted using ASAP Micrometric at $77 \mathrm{~K}$. Sample was degassed under liquid nitrogen several times prior to analysis. The thermal stability of the material was measured using TG-DTA Shimadzu under atmospheric nitrogen. The temperature analysis was at room temperature to $800{ }^{\circ} \mathrm{C}$. Material photos were obtained using SEM-EDX Quanta-650 Oxford Instrument. The concentration of methylene blue was analyzed using UV-Visible spectrophotometer BIOBase BK-UV 1800 PC at wavelength $664 \mathrm{~nm}$.

\section{Procedure}

\section{Synthesis of Ni/AI LDH}

Synthesis of Ni/Al LDH was conducted using the coprecipitation method at $\mathrm{pH} 10$ [28]. Nickel(II) nitrate and aluminum(III) nitrate with equal volume and concentration ratio $(3: 1)$ were mixed and stirred at room temperature. Sodium carbonate $(0.3 \mathrm{M})$ was added with equal volume slowly and sodium hydroxide to achieve $\mathrm{pH}$ 10. The reaction mixture was kept at $80^{\circ} \mathrm{C}$ for $18 \mathrm{~h}$. The solid material was obtained and washed with water, and dried at $110^{\circ} \mathrm{C}$.

\section{Synthesis of composite Ni/AI LDH-biochar}

Synthesis of NiAl LDH/Biochar was conducted by mixing the co-precipitation method. The solution of nickel(II) nitrate $0.3 \mathrm{M}$ and aluminum(III) nitrate $0.1 \mathrm{M}$ with equal volume was mixed for $60 \mathrm{~min}$. Biochar ( $3 \mathrm{~g}$ ) was added to the reaction mixture following by the addition of sodium hydroxide ( $2 \mathrm{M}$ ). The $\mathrm{pH}$ mixture was adjusted to 10 by adding sodium hydroxide. The reaction was kept for $72 \mathrm{~h}$ with constant stirring. The solid material was obtained and washed several times with water, and dried at $110^{\circ} \mathrm{C}$ for several days.

\section{Adsorption process}

Adsorption was studied by variation of $\mathrm{pH}$ solution, adsorption time, initial concentration, and adsorption temperature using $0.1 \mathrm{~g}$ of $\mathrm{NiAl} \mathrm{LDH} /$ Biochar and starting materials as control. The adsorption was conducted using a batch small reactor system equipped with shaking apparatus control. The variation $\mathrm{pH}$ solution was 2-10. Adsorption time was conducted at 5$200 \mathrm{~min}$. Adsorption temperature was carried out at 30 , 40,50 , and $60{ }^{\circ} \mathrm{C}$ using an initial concentration of methylene blue from $5-20 \mathrm{mg} / \mathrm{L}$ for NiAl LDH as adsorbent, 5-40 mg/L for biochar, and 5-60 mg/L for $\mathrm{NiAl} \mathrm{LDH} /$ Biochar. All filtrate of methylene blue was analyzed using UV-Visible at wavelength $664 \mathrm{~nm}$.

\section{Desorption and regeneration}

Desorption of methylene blue after the adsorption process was conducted using several solvents such as ethanol, acetone, diethyl ether, water, hydrochloric acid, and sodium hydroxide. The solvent has been classified as organic and inorganic solvents. The filtrate from the desorption process was measured using UV-Vis at $664 \mathrm{~nm}$.

Prior regeneration process, the adsorbent was desorbed using maximum desorption solvent followed by washed using water several times, dried at $110{ }^{\circ} \mathrm{C}$ overnight, and ready to use. The cycle of adsorption was conducted three times the cycle for adsorption of methylene blue using a similar adsorbent.

\section{- RESULTS AND DISCUSSION}

The results of XRD pattern of NiAl LDH/Biochar, biochar, and Ni/Al LDH were shown in Fig. 2. Fig. 2(a) showed Ni/Al LDH has peak at $11.63^{\circ}(003) ; 23.00^{\circ}$ (006); $35.16^{\circ}(012) ; 39.56^{\circ}(015) ; 47.4^{\circ}(018)$ and $61.59^{\circ}$ (110). The formation of a well-layered structure of $\mathrm{Ni} / \mathrm{Al}$ was identified at 11.63 (003) and 61.59 (110) [29]. These results are appropriate with Tao et al. (2019) where the crystallinity of Ni/Al LDH was high [30]. Fig. 2(b) shows the diffraction of biochar. Biochar is an organic compound; thus, the diffraction peak is board due to the high organic content on the material. The diffraction peak at $22.30^{\circ}(002)$ for biochar was characteristic of organic content, especially carbon [31-32]. Fig. 2(c) shows the NiAl LDH/Biochar based Ni/Al LDH and biochar. The diffraction peak of $\mathrm{NiAl} \mathrm{LDH} /$ Biochar is a little broad, with several peaks were identified at $11.63^{\circ}$ and $22.30^{\circ}$. These two peaks are $\mathrm{Ni} / \mathrm{Al} \mathrm{LDH}$ and biochar 


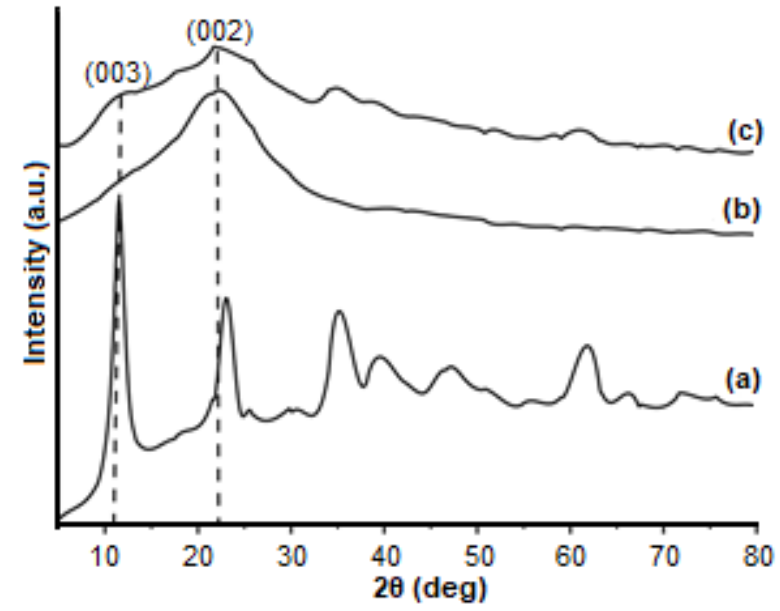

Fig 2. X-ray diffraction of Ni/Al LDH (a), biochar (b), and $\mathrm{NiAl}$ LDH/Biochar (c)

characterized; thus, NiAl LDH/Biochar consists of LDH and biochar.

FTIR spectrum of materials was presented in Fig. 3. Fig. 3(a) shows the IR spectrum of Ni/Al LDH. The peak vibration was appeared at $3664 \mathrm{~cm}^{-1}$ (v O-H stretching), $1630 \mathrm{~cm}^{-1}$ (v O-H bending), $1381 \mathrm{~cm}^{-1}$ ( $\mathrm{v} \mathrm{N}-\mathrm{O}$ nitrate), $748 \mathrm{~cm}^{-1}$ ( $\mathrm{v} \mathrm{Al}-\mathrm{O}$, trivalent metal), and $563 \mathrm{~cm}^{-1}(\mathrm{v} \mathrm{Ni}-$ O, divalent metal) [24]. Fig. 3(b) shows the FTIR spectrum of biochar. There are several peaks identified at wavenumber $3448 \mathrm{~cm}^{-1}, 2924 \mathrm{~cm}^{-1}, 2854 \mathrm{~cm}^{-1}, 2368 \mathrm{~cm}^{-1}$, $2337 \mathrm{~cm}^{-1}, 1620 \mathrm{~cm}^{-1}$, and $1130 \mathrm{~cm}^{-1}$. All these vibrations were identified in the fingerprint area and consist of an organic vibration component [33]. Fig. 3(c) shows the FTIR spectrum of NiAl LDH/Biochar. The peaks are found at $3441 \mathrm{~cm}^{-1}, 2931 \mathrm{~cm}^{-1}, 2368 \mathrm{~cm}^{-1}, 2283 \mathrm{~cm}^{-1}$, $1627 \mathrm{~cm}^{-1}, 1381 \mathrm{~cm}^{-1}, 1049 \mathrm{~cm}^{-1}$, and $578 \mathrm{~cm}^{-1}$. All these vibrations contain vibrations of $\mathrm{Ni} / \mathrm{Al} \mathrm{LDH}$ and biochar. Thus, NiAl LDH/Biochar in this research is based on two components.

The nitrogen adsorption-desorption analysis data of $\mathrm{Ni} / \mathrm{Al} \mathrm{LDH}$, biochar, and NiAl LDH/Biochar was shown in Fig. 4. The isotherm in Fig. 4 shows a hysteresis loop where the adsorption curve has a different type from the desorption step. The NiAl LDH/Biochar has a type II isotherm model, and the material has a mesoporous class with contains a larger pore than the microporous type [34]. The isotherm data in Fig. 4 was then used to obtain surface area, pore-volume, and pore diameter, as shown in Table 1.

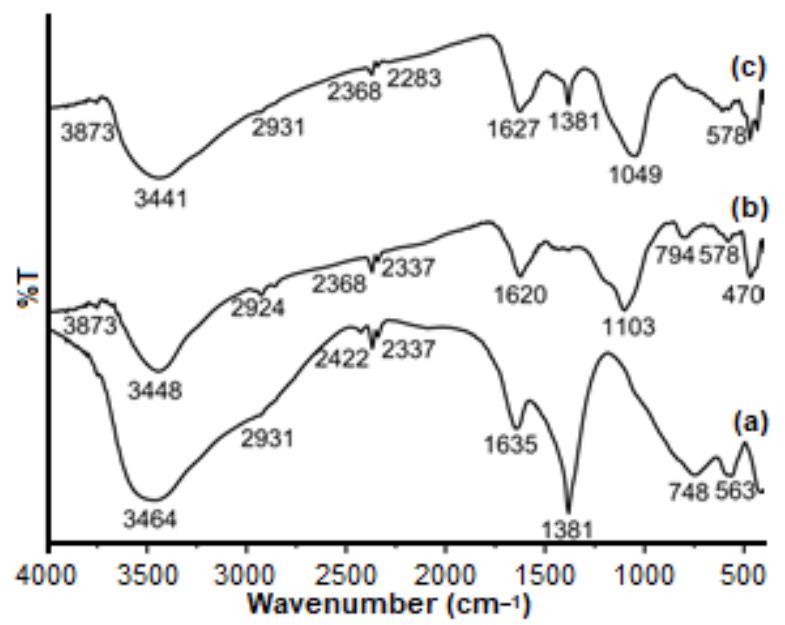

Fig 3. FTIR spectrum of Ni/Al LDH (a), biochar (b), and $\mathrm{NiAl}$ LDH/Biochar (c)

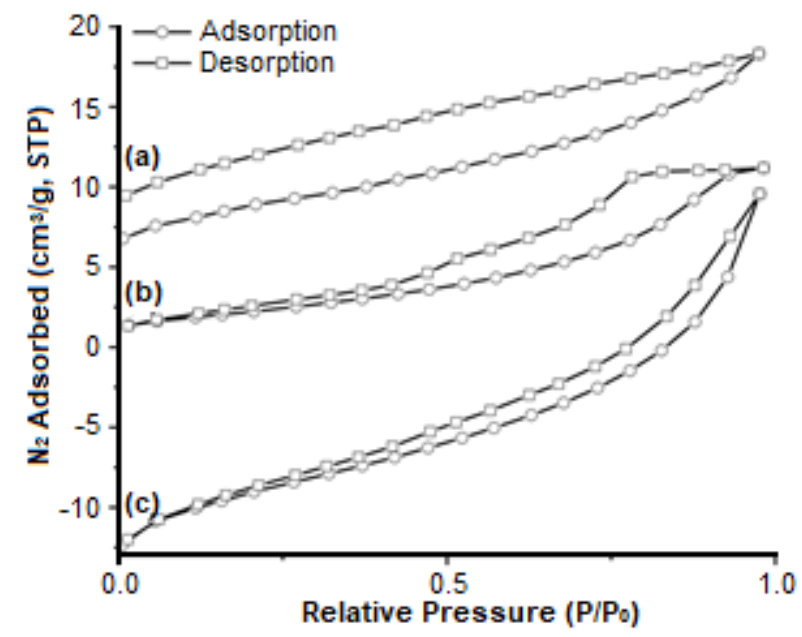

Fig 4. Nitrogen adsorption-desorption profile of $\mathrm{Ni} / \mathrm{Al}$ LDH (a), biochar (b), and NiAl LDH/Biochar (c)

Table 1. BET surface area analysis

\begin{tabular}{lccc}
\hline Materials & $\begin{array}{c}\text { Surface area } \\
\left(\mathrm{m}^{2} / \mathrm{g}\right)\end{array}$ & $\begin{array}{c}\text { Pore volume } \\
\left(\mathrm{cm}^{3} / \mathrm{g}\right)\end{array}$ & $\begin{array}{c}\text { Pore diameter } \\
(\mathrm{nm})\end{array}$ \\
\hline $\mathrm{Ni} / \mathrm{Al} \mathrm{LDH}$ & 92.683 & 0.001 & 13.206 \\
Biochar & 50.936 & 0.002 & 12.088 \\
NiAl LDH/Biochar & 438.942 & 0.002 & 12.301 \\
\hline
\end{tabular}


Table 1 shows NiAl LDH/Biochar has large surface area properties than $\mathrm{Ni} / \mathrm{Al} \mathrm{LDH}$ and biochar. The NiAl $\mathrm{LDH} /$ Biochar has a surface area of $438.942 \mathrm{~m}^{2} / \mathrm{g}$ and almost ten-fold higher than starting materials. These phenomena are probably due to the biochar as matrixassisted to reduce the size and agglomeration of LDH [23].

The TG-DTA pattern of the material was presented in Fig. 5. Ni/Al $\mathrm{LDH}$ has two endothermic peaks at $90^{\circ} \mathrm{C}$ and $310^{\circ} \mathrm{C}$, which is assigned as water loss and nitrate on interlayer LDH decomposition. On the other hand, the DTA profile of biochar contains not only an endothermic peak but also an exothermic peak. The endothermic peak was found at $95{ }^{\circ} \mathrm{C}$ due to the loss of water of crystallization [11]. The exothermic peak was found at $500{ }^{\circ} \mathrm{C}$ because of the oxidation of organic compounds on biochar [35]. The TG-DTA pattern of NiAl LDH/Biochar was shown in Fig. 5(c) and contained one endothermic peak at $95^{\circ} \mathrm{C}$ and two exothermic peaks at $430{ }^{\circ} \mathrm{C}$ and $500{ }^{\circ} \mathrm{C}$. The exothermic peaks are the $\mathrm{LDH}$ decomposition peak, and the endothermic peak is the oxidation of organic biochar.

The surface material photos were presented in Fig. 6. The layer structure of Ni/Al was seen in Fig. 6(a) with the agglomeration process. The biochar, as seen in Fig. 6(b) has an irregular pore. The NiAl LDH/Biochar shown in Fig. 6(c) has small particle distribution than
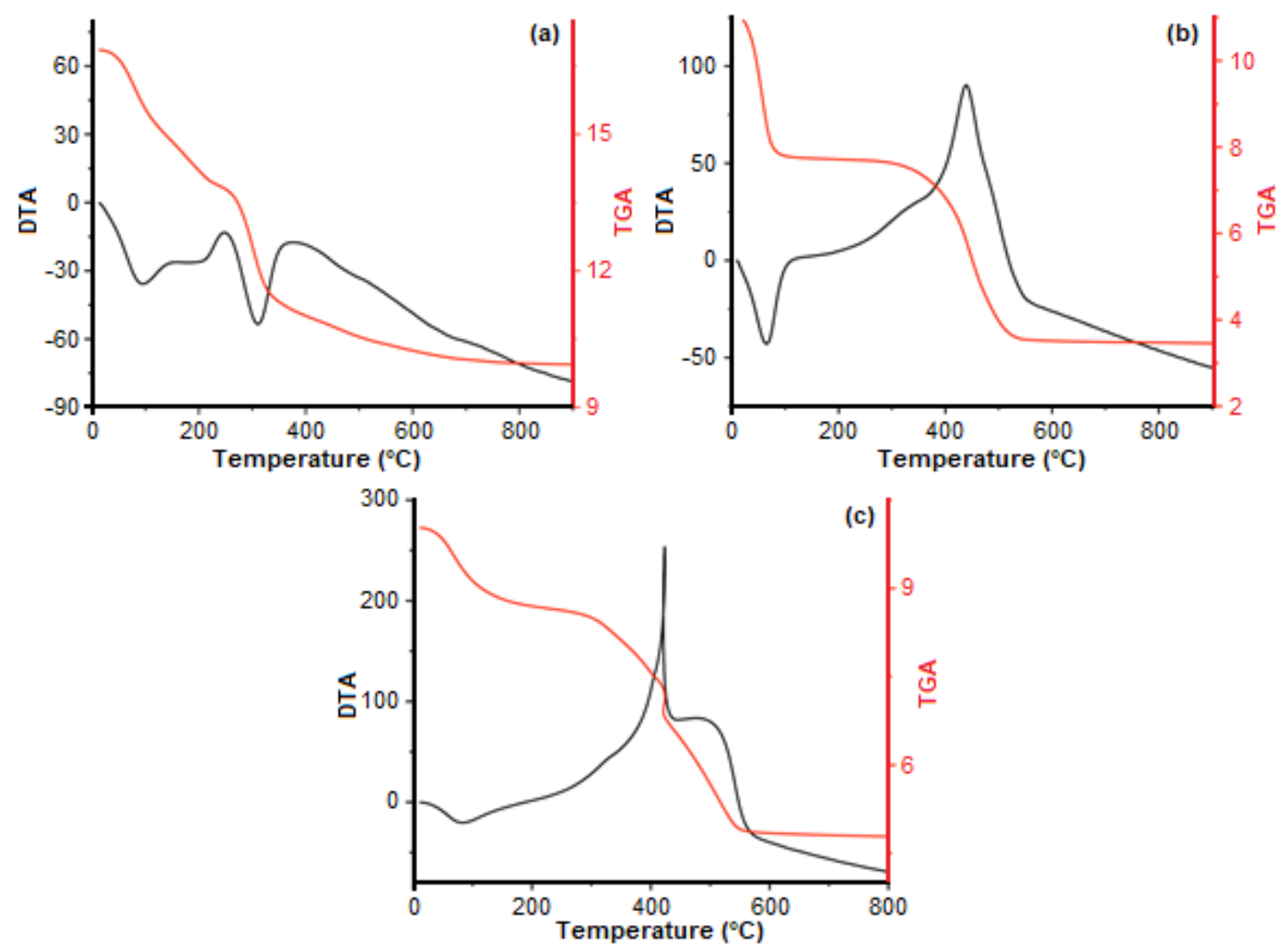

Fig 5. TG-DTA profile of Ni/Al LDH (a), biochar (b), and NiAl LDH/Biochar (c)

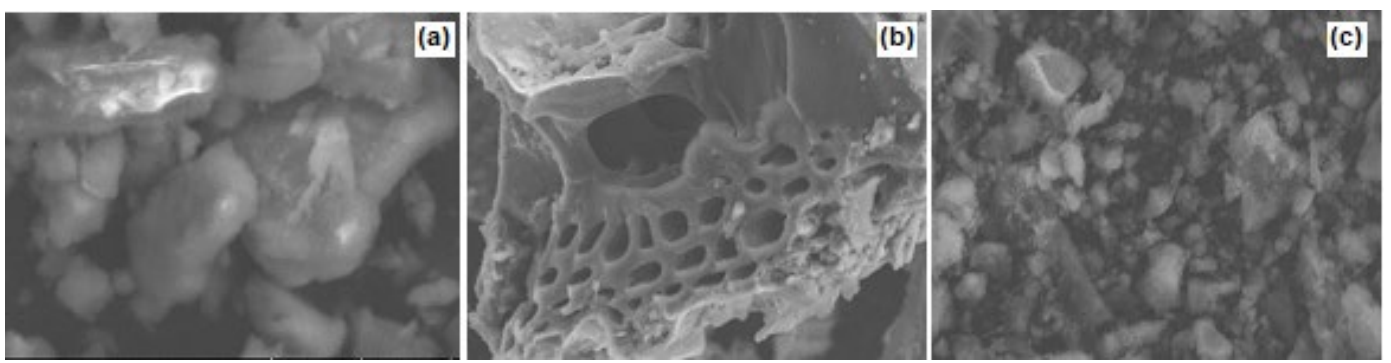

Fig 6. Surface photo of materials 
$\mathrm{Ni} / \mathrm{Al} \mathrm{LDH}$ with minor agglomeration. These photos in Fig. 6(c) are related to a high surface area of NiAl $\mathrm{LDH} /$ Biochar in this research.

The composition of materials analysis using EDX was shown in Table 2. The main composition of LDH was nickel, aluminum, oxygen, and nitrogen. Nitrogen is higher because nitrate ion was located on the interlayer scape of LDH. Biochar has high carbon content (58.3\%). The NiAl LDH/Biochar contains all elements of starting materials except carbon because carbon is associated with oxygen in the agglomeration process, and the percentage of oxygen will be higher than starting materials.

The effect of the $\mathrm{pH}$ medium of methylene blue adsorption on Ni/Al LDH, biochar, and NiAl LDH/Biochar is shown in Fig. 7. The optimum $\mathrm{pH}$ for $\mathrm{NiAl} \mathrm{LDH/Biochar,} \mathrm{biochar,} \mathrm{and} \mathrm{NiAl} \mathrm{LDH} \mathrm{was} \mathrm{4,} \mathrm{4,} \mathrm{and}$ 3. All adsorbents have methylene blue adsorption at acid medium. The solution of methylene blue has a $\mathrm{pH}$ range of $3.0-4.3$, the optimum $\mathrm{pH}$ adsorption using $\mathrm{NiAl}$ $\mathrm{LDH} /$ Biochar, biochar, and $\mathrm{Ni} / \mathrm{Al} \mathrm{LDH}$ is inside the natural range of methylene blue, for further adsorption was conducted at this optimum $\mathrm{pH}$.

Fig. 8 shows the effect of adsorption time and fitting with kinetic pseudo-first-order (PF-O) and pseudosecond-order (PS-O). The amount of methylene blue adsorbed on $\mathrm{NiAl} \mathrm{LDH} /$ Biochar, biochar, and $\mathrm{Ni} / \mathrm{Al} \mathrm{LDH}$ was gradually increased by increasing adsorption time until optimum. The amount of methylene blue stable on the adsorbent. The optimum adsorption time for NiAl $\mathrm{LDH} /$ Biochar, biochar, and $\mathrm{Ni} / \mathrm{Al} \mathrm{LDH}$ is started from $150 \mathrm{~min}$, as shown in the black circle symbol. These data then were applied to obtain PF-O and PS-O using the equation as following [36]:
PF-O:

$\log \left(\mathrm{q}_{\mathrm{e}}-\mathrm{q}_{\mathrm{t}}\right)=\log \mathrm{q}_{\mathrm{e}}-\left(\frac{\mathrm{k}_{1}}{2.303}\right) \mathrm{t}$

where: $\mathrm{q}_{\mathrm{e}}$ is adsorption capacity at the equilibrium (mg $\left.\mathrm{g}^{-1}\right)$; $\mathrm{q}_{\mathrm{t}}$ is adsorption capacity at $\mathrm{t} \min \left(\mathrm{mg} \mathrm{g}^{-1}\right)$; $\mathrm{t}$ is adsorption time $(\mathrm{min})$, and $\mathrm{k}_{1}$ is kinetic adsorption rate at PF-O $\left(\mathrm{min}^{-1}\right)$.

PS-O:

$\frac{\mathrm{t}}{\mathrm{q}_{\mathrm{t}}}=\frac{1}{\mathrm{k}_{2} \mathrm{q}_{\mathrm{e}}^{2}}+\frac{1}{\mathrm{q}_{\mathrm{e}}} \mathrm{t}$

where $\mathrm{q}_{\mathrm{e}}$ is adsorption capacity at the equilibrium ( $\mathrm{mg}$ $\left.\mathrm{g}^{-1}\right) ; \mathrm{q}_{\mathrm{t}}$ is adsorption capacity at $\mathrm{t} \min \left(\mathrm{mg} \mathrm{g}^{-1}\right)$; $\mathrm{t}$ is adsorption time ( $\mathrm{min}$ ), and $\mathrm{k}_{2}$ is adsorption rate at $\mathrm{PS}-\mathrm{O}$ $\left(\mathrm{g} \mathrm{mg}^{-1} \mathrm{~min}^{-1}\right)$. The PF-O and PS-O results are shown in Table 3.

The data in Table 3 showed that the $\mathrm{R}^{2}$ value for $\mathrm{NiAl} \mathrm{LDH} /$ Biochar and biochar is closed to one for PS-O. On the other hand, Ni/Al LDH has $\mathrm{R}^{2}$ closed to one

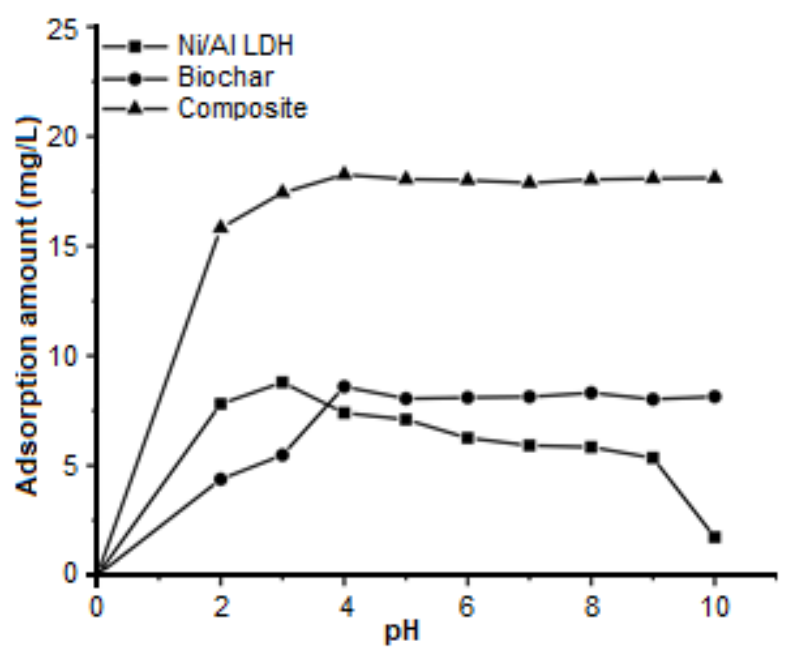

Fig 7. The $\mathrm{pH}$ adsorption effect of methylene blue on $\mathrm{Ni} / \mathrm{Al} \mathrm{LDH}$, biochar, and NiAl LDH/Biochar

Table 2. Analysis composition of materials by EDX

\begin{tabular}{crcccr}
\hline \multicolumn{2}{c}{$\mathrm{Ni} /$ Al LDH } & \multicolumn{2}{c}{ Biochar } & \multicolumn{2}{c}{ NiAl LDH/Biochar } \\
\hline Element & $(\%)$ & Element & $(\%)$ & Element & $(\%)$ \\
\hline $\mathrm{Ni}$ & 88.3 & $\mathrm{C}$ & 58.3 & $\mathrm{Ni}$ & 14.6 \\
$\mathrm{Al}$ & 1.3 & $\mathrm{O}$ & 27.3 & $\mathrm{Al}$ & 3.3 \\
$\mathrm{O}$ & 1.4 & $\mathrm{Si}$ & 11.0 & $\mathrm{~N}$ & 1.3 \\
$\mathrm{~N}$ & 9.1 & $\mathrm{Al}$ & 3.3 & $\mathrm{O}$ & 55.6 \\
& & & & $\mathrm{Si}$ & 25.2 \\
\hline
\end{tabular}



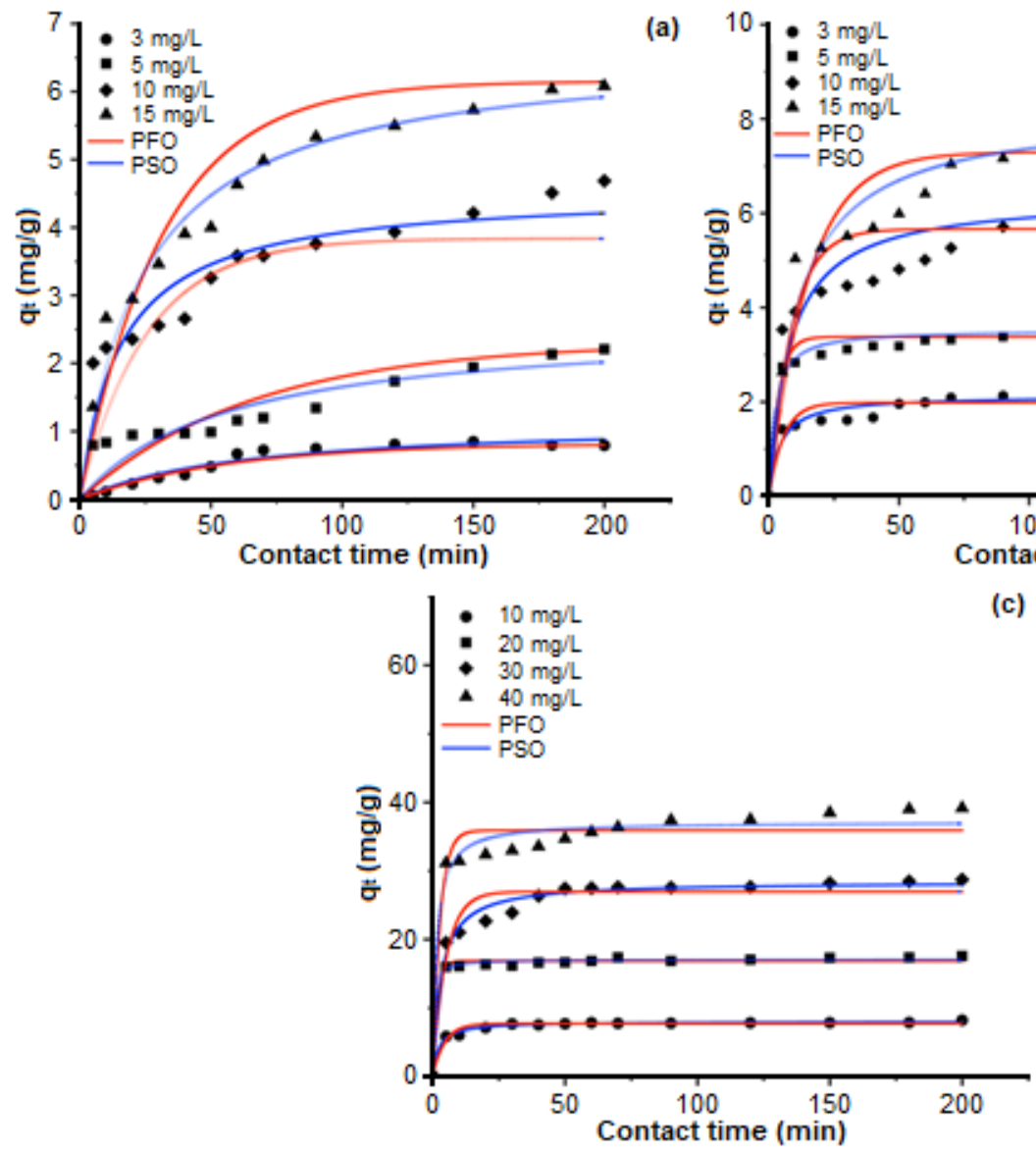

(b)

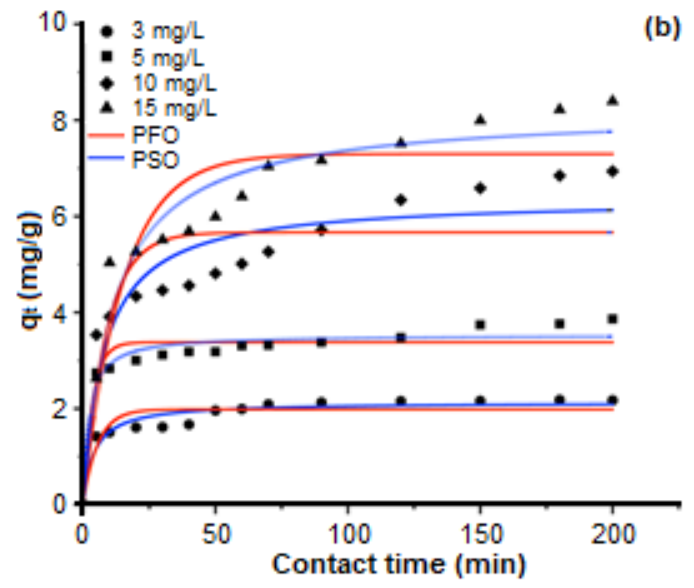

(c)

Fig 8. Kinetic adsorption of methylene blue on Ni/Al LDH (a), biochar (b), and NiAl LDH/Biochar (c)

Table 3. Kinetic parameter of pseudo first-order and second-order

\begin{tabular}{|c|c|c|c|c|c|}
\hline Kinetic Models & Parameter & $3 \mathrm{mg} / \mathrm{L}$ & $5 \mathrm{mg} / \mathrm{L}$ & $10 \mathrm{mg} / \mathrm{L}$ & $15 \mathrm{mg} / \mathrm{L}$ \\
\hline \multicolumn{6}{|c|}{$\mathrm{Ni} / \mathrm{Al} \mathrm{LDH}$} \\
\hline \multirow{4}{*}{ Pseudo first order } & $\mathrm{q}_{\mathrm{e}} \exp (\mathrm{mg} / \mathrm{g})$ & 0.396 & 1.183 & 2.343 & 3.258 \\
\hline & $\mathrm{q}_{\mathrm{e}}$ calc $(\mathrm{mg} / \mathrm{g})$ & 1.924 & 1.073 & 1.603 & 2.922 \\
\hline & $\mathrm{k}_{1}\left(\min ^{-1}\right)$ & 0.033 & 0.012 & 0.014 & 0.022 \\
\hline & $\mathrm{R}^{2}$ & 0.921 & 0.921 & 0.955 & 0.939 \\
\hline \multirow{4}{*}{ Pseudo second order } & $\mathrm{q}_{\mathrm{e}} \exp (\mathrm{mg} / \mathrm{g})$ & 0.396 & 1.183 & 2.343 & 3.258 \\
\hline & $\mathrm{q}_{\mathrm{e}}$ calc $(\mathrm{mg} / \mathrm{g})$ & 0.620 & 10.417 & 7.299 & 4.484 \\
\hline & $\mathrm{k}_{2}(\mathrm{~g} / \mathrm{mg} \min )$ & 0.020 & 0.004 & 0.004 & 0.014 \\
\hline & $\mathrm{R}^{2}$ & 0.900 & 0.964 & 0.920 & 0.917 \\
\hline \multicolumn{6}{|c|}{ Biochar } \\
\hline \multirow{4}{*}{ Pseudo first Order } & $\mathrm{q}_{\mathrm{e}} \exp (\mathrm{mg} / \mathrm{g})$ & 1.085 & 1.932 & 3.469 & 4.198 \\
\hline & $\mathrm{q}_{\mathrm{e}}$ calc $(\mathrm{mg} / \mathrm{g})$ & 1.554 & 1.312 & 2.582 & 2.843 \\
\hline & $\mathrm{k}_{1}\left(\min ^{-1}\right)$ & 0.035 & 0.015 & 0.020 & 0.018 \\
\hline & $\mathrm{R}^{2}$ & 0.961 & 0.857 & 0.929 & 0.961 \\
\hline \multirow{4}{*}{ Pseudo second order } & $\mathrm{q}_{\mathrm{e}} \exp (\mathrm{mg} / \mathrm{g})$ & 1.085 & 1.932 & 3.469 & 4.198 \\
\hline & $\mathrm{q}_{\mathrm{e}}$ calc $(\mathrm{mg} / \mathrm{g})$ & 1.133 & 1.951 & 7.633 & 2.222 \\
\hline & $\mathrm{k}_{2}(\mathrm{~g} / \mathrm{mg} \min )$ & 0.114 & 0.062 & 0.006 & 0.104 \\
\hline & $\mathrm{R}^{2}$ & 0.997 & 0.995 & 0.971 & 0.942 \\
\hline
\end{tabular}

Aldes Lesbani et al. 
Table 3. Kinetic parameter of pseudo first-order and second-order (Continued)

\begin{tabular}{|c|c|c|c|c|c|}
\hline Kinetic Models & Parameter & $3 \mathrm{mg} / \mathrm{L}$ & $5 \mathrm{mg} / \mathrm{L}$ & $10 \mathrm{mg} / \mathrm{L}$ & $15 \mathrm{mg} / \mathrm{L}$ \\
\hline \multicolumn{6}{|c|}{ NiAl LDH/Biochar } \\
\hline \multirow{4}{*}{ Pseudo first order } & $\mathrm{q}_{\mathrm{e}} \exp (\mathrm{mg} / \mathrm{g})$ & 4.103 & 8.787 & 14.368 & 19.586 \\
\hline & $\mathrm{q}_{\mathrm{e}}$ calc $(\mathrm{mg} / \mathrm{g})$ & 1.402 & 2.345 & 4.249 & 5.532 \\
\hline & $\mathrm{k}_{1}\left(\min ^{-1}\right)$ & 0.025 & 0.032 & 0.020 & 0.020 \\
\hline & $\mathrm{R}^{2}$ & 0.581 & 0.587 & 0.823 & 0.944 \\
\hline \multirow{4}{*}{ Pseudo second order } & $\mathrm{q}_{\mathrm{e}} \exp (\mathrm{mg} / \mathrm{g})$ & 4.103 & 8.787 & 14.368 & 19.586 \\
\hline & $\mathrm{q}_{\mathrm{e}} \mathrm{calc}(\mathrm{mg} / \mathrm{g})$ & 4.061 & 8.787 & 14.577 & 19.920 \\
\hline & $\mathrm{k}_{2}(\mathrm{~g} / \mathrm{mg} \min )$ & 0.083 & 0.057 & 0.015 & 0.009 \\
\hline & $\mathrm{R}^{2}$ & 0.999 & 0.999 & 0.999 & 0.999 \\
\hline
\end{tabular}

for PF-O. The main reason is probably due to the inorganic-organic adsorbent character for $\mathrm{NiAl}$ LDH/Biochar, biochar, and Ni/Al LDH. Furthermore, the value of $\mathrm{k}_{2}$ for $\mathrm{NiAl} \mathrm{LDH} /$ Biochar and biochar was decreased with increasing concentration of methylene blue. These phenomena are also similar for $\mathrm{k}_{1}$ of $\mathrm{Ni} / \mathrm{Al}$ $\mathrm{LDH}$. The reason is that the mobility of the concentrated sample is lower than the aqueous sample. The value of $\mathrm{k}_{2}$ is getting low for both the dyes, which indicates that the adsorption process is rapid. It means that two molecules can be adsorbed in a single site, or a single molecule can interact with two adsorption sites. Furthermore, this finding also supports that the adsorption rate depends on active sites proposing a chemisorption process.

The effect of initial concentration and temperature adsorption of methylene blue on NiAl LDH/Biochar, biochar, and Ni/Al LDH was presented in Fig. 9. The amount of methylene blue adsorbed on materials was sharply increased by increasing the initial concentration of methylene blue and temperature. The adsorption patterns for $\mathrm{Ni} / \mathrm{Al} \mathrm{LDH}$ and biochar were similar to the form two stages adsorption step. Still, NiAl LDH/Biochar has a straight adsorption pattern toward initial concentration and temperature. The isotherm Langmuir and Freundlich, as shown in Table 4 was obtained from data in Fig. 8 using the equation as following [37]:

Langmuir:

$\frac{\mathrm{C}}{\mathrm{m}}=\frac{1}{\mathrm{bK}_{\mathrm{L}}}+\frac{\mathrm{C}}{\mathrm{b}}$

where $\mathrm{C}$ is a saturated concentration of adsorbate; $\mathrm{m}$ is the amount of adsorbate; $b$ is the maximum adsorption capacity $\left(\mathrm{mg} \mathrm{g}^{-1}\right)$, and $\mathrm{K}_{\mathrm{L}}$ is the Langmuir constant ( $\mathrm{L}$ $\left.\mathrm{mg}^{-1}\right)$.

Freundlich:

$\log \mathrm{q}_{\mathrm{e}}=\log \mathrm{K}_{\mathrm{F}}+1 / \mathrm{n} \log \mathrm{C}_{\mathrm{e}}$

where $\mathrm{q}_{\mathrm{e}}$ is adsorption capacity at equilibrium $\left(\mathrm{mg} \mathrm{g}^{-1}\right)$; $\mathrm{C}_{\mathrm{e}}$ is the adsorbate concentration at equilibrium $\left(\mathrm{mg} \mathrm{L}^{-1}\right)$, and $\mathrm{K}_{\mathrm{F}}$ is Freundlich constant. Table 4 showed the maximum adsorption capacity of Langmuir by NiAl $\mathrm{LDH} /$ Biochar was $61.728 \mathrm{mg} / \mathrm{g}$, which is relatively higher than some previously reported in Table 5. Table 5 was shown the comparison of the adsorption capacity of methylene blue using several adsorbents.

The data in Table 4 showed that the adsorption of methylene blue on NiAl LDH/Biochar, biochar, and $\mathrm{Ni} / \mathrm{Al} \mathrm{LDH}$ almost follows the Langmuir isotherm adsorption model rather than the Freundlich model. The $\mathrm{R}^{2}$ for Langmuir isotherm is nearly close to one than Freundlich isotherm. The $\mathrm{Q}_{\mathrm{m}}$ for NiAl LDH/Biochar is higher than biochar and $\mathrm{Ni} / \mathrm{Al} \mathrm{LDH}$. As expected of increasing surface area properties, this higher $\mathrm{Q}_{\mathrm{m}}$ is a logical result.

The thermodynamic data, as shown in Table 6, was also calculated from data in Fig. 9 using the equation as follow:

$\ln \mathrm{K}_{\mathrm{L}}=\frac{\Delta \mathrm{S}}{\mathrm{R}}-\frac{\Delta \mathrm{H}}{\mathrm{RT}}$
$\Delta \mathrm{G}^{\circ}=-\mathrm{RT} \ln \mathrm{K}_{\mathrm{L}}$

where $\mathrm{T}$ is the temperature $(\mathrm{K}), \mathrm{R}$ is the gas constant $\left(8.314 \mathrm{~J} \mathrm{~mol}^{-1} \mathrm{~K}^{-1}\right)$, and $\mathrm{K}_{\mathrm{L}}$ is the Langmuir constant from Table 4.

For all methylene blue conditions, the $\Delta \mathrm{G}$ of 

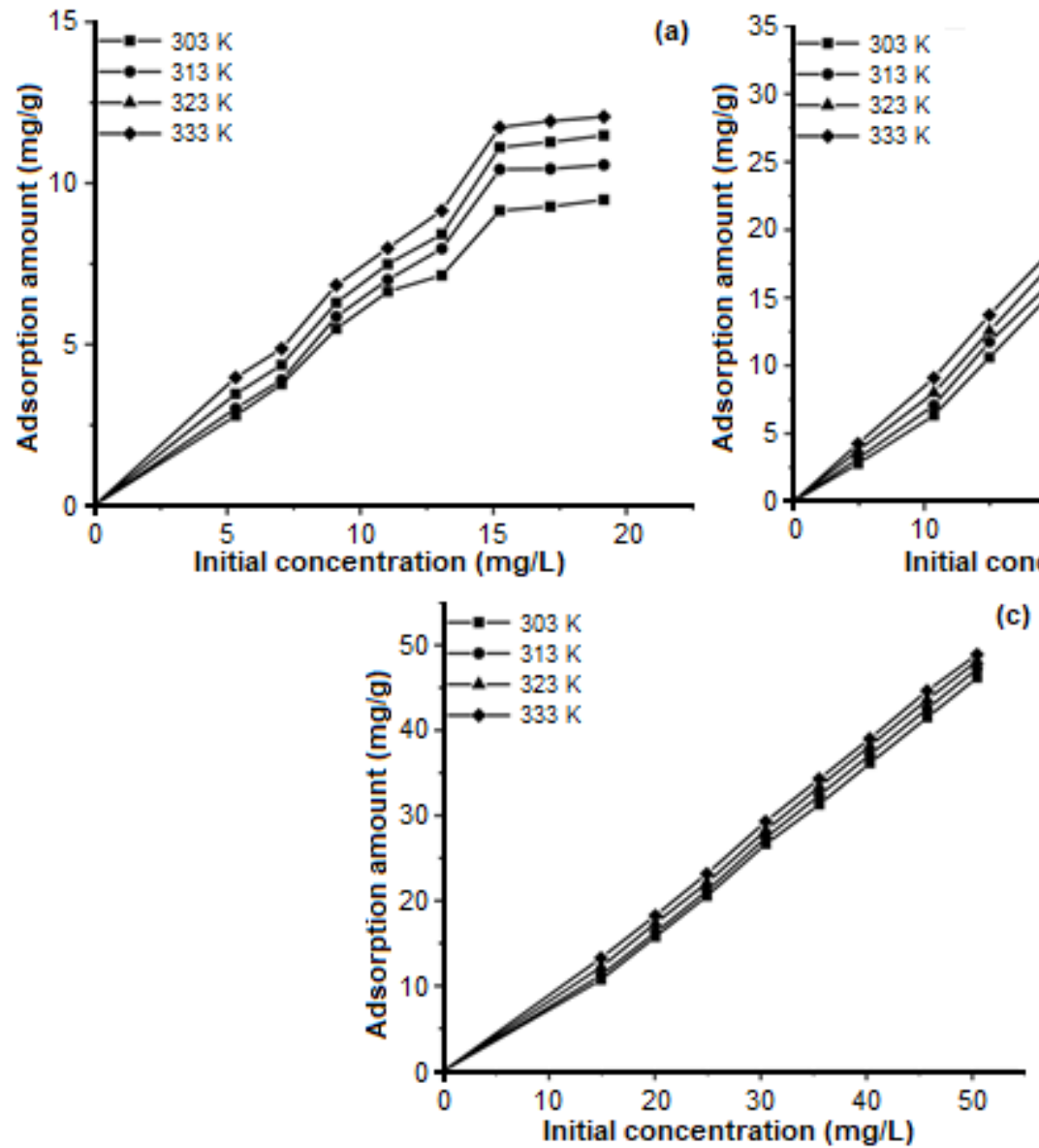

(b)

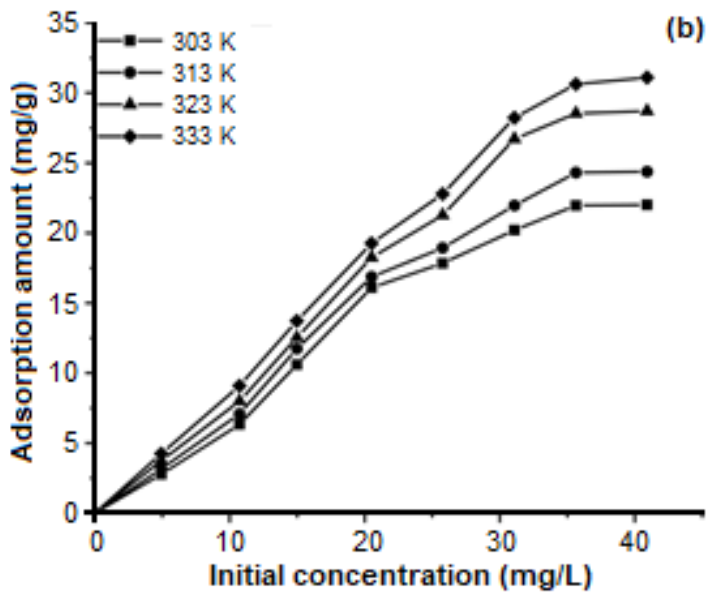

(c)

Fig 9. The effect of initial concentration and temperature adsorption on Ni/Al LDH (a), biochar (b), and NiAl $\mathrm{LDH} /$ Biochar (c)

Table 4. The isotherm adsorption of methylene blue

\begin{tabular}{lcccccc}
\hline \multirow{2}{*}{ Adsorbent } & \multicolumn{5}{c}{ Isotherm } \\
\cline { 2 - 7 } & $\mathrm{Q}_{\mathrm{m}}$ & $\mathrm{K}_{\mathrm{L}}$ & $\mathrm{R}^{2}$ & $\mathrm{n}$ & $\mathrm{K}_{\mathrm{F}}$ & $\mathrm{R}^{2}$ \\
\cline { 2 - 7 } & 22.989 & 0.173 & 0.919 & 1.477 & 3.603 & 0.953 \\
NiAl LDH & 36.101 & 0.622 & 0.990 & 4.296 & 1.336 & 0.993 \\
Biochar & 61.728 & 0.354 & 0.945 & 0.621 & 1.423 & 0.987 \\
\hline
\end{tabular}

adsorption has a negative value means adsorption of methylene blue on NiAl LDH/Biochar, biochar, and $\mathrm{Ni} / \mathrm{Al} \mathrm{LDH}$ have spontaneously occurred in a batch small reactor system. The $\Delta \mathrm{H}$ value is less than $80 \mathrm{~kJ} / \mathrm{mol}$ and in the range $15.502-43.402 \mathrm{~kJ} / \mathrm{mol}$ for all adsorbents. This value belongs to chemi-physical adsorption [51]. The value of $\Delta S$ is irregular for increasing methylene blue concentration means growing randomness for adsorption of methylene blue on the adsorbent.
Desorption of methylene blue on NiAl $\mathrm{LDH} /$ Biochar and starting materials were conducted using several reagents such as ethanol, acetone, diethyl ether, sodium hydroxide solution, hydrochloric acid solution, and water. The results are shown in Figure 10. NiAl LDH/Biochar and biochar were efficiently desorbed using acetone and $\mathrm{Ni} / \mathrm{Al} \mathrm{LDH}$ using hydrochloric acid. The involvement of acid-base reaction in the desorption using $\mathrm{Ni} / \mathrm{Al} \mathrm{LDH}$ was dominated, 
Table 5. Comparison of the adsorption capacity of methylene blue

\begin{tabular}{lcc}
\hline \multicolumn{1}{c}{ Adsorbent } & $\begin{array}{c}\text { Adsorption capacity } \\
(\mathrm{mg} / \mathrm{g})\end{array}$ & References \\
\hline Wheat shells & 21.50 & {$[38]$} \\
Activated biochar-TA & 53.28 & {$[39]$} \\
${\mathrm{MW}-S i O_{2}}_{\mathrm{MgAl} \text { LDO }}$ & 186.1 & {$[40]$} \\
Cockle Shells-Treated Banana Pith & 49.53 & {$[41]$} \\
MgAl LDH & 85.47 & {$[42]$} \\
Alginate Beads Powder & 49 & {$[43]$} \\
Activated Carbon & 48.2 & {$[44]$} \\
Fe/SCD-LDH & 11.40 & {$[45]$} \\
Orange Peels & 83.40 & {$[46]$} \\
Rice husk & 18.60 & {$[10]$} \\
Catton Waste & 40.58 & {$[47]$} \\
Ca/Al LDH-biochar & 24.00 & {$[48]$} \\
LDH-bacteria aggregates & 32.535 & {$[49]$} \\
NiAl/Biochar & 5.23 & {$[50]$} \\
\hline
\end{tabular}

Table 6. The thermodynamic parameter adsorption of methylene blue

\begin{tabular}{lccccc}
\hline Initial Concentration & $\mathrm{T}(\mathrm{K})$ & $\mathrm{Q}_{\mathrm{e}}(\mathrm{mg} / \mathrm{g})$ & $\Delta \mathrm{H}(\mathrm{kJ} / \mathrm{mol})$ & $\Delta \mathrm{S}(\mathrm{J} / \mathrm{mol} \mathrm{K})$ & $\Delta \mathrm{G}(\mathrm{kJ} / \mathrm{mol})$ \\
\hline \multirow{3}{*}{$\mathrm{NiAl} \mathrm{LDH}$} & 303 & 9.489 & 15.502 & 0.051 & -0.489 \\
& 313 & 10.570 & & & -1.094 \\
& 323 & 11.479 & & & -1.700 \\
& 333 & 12.061 & & & -2.306 \\
Biochar & 303 & 16.097 & 40.951 & 0.145 & -2.945 \\
& 313 & 16.873 & & & -4.394 \\
& 323 & 18.255 & & & -5.843 \\
& 333 & 19.269 & & & -7.292 \\
NiAl LDH/Biochar & 303 & 15.661 & 43.402 & & -2.883 \\
& 313 & 16.533 & & & -4.410 \\
& 323 & 17.878 & & & -5.938 \\
\hline
\end{tabular}

but like dissolve like principle [52] is found in the desorption of methylene blue on NiAl LDH/Biochar and biochar.

The regeneration of adsorbent was studied after desorption using suitable reagents as described in Fig. 10 following by washing by water several times and dried at $110{ }^{\circ} \mathrm{C}$. It was performed until three-cycle adsorption of methylene blue using the same adsorbent from fresh materials. The results of the regeneration process are shown in Fig. 11. The reusability of Ni/Al LDH and biochar was sharply decreased for second and third cycle adsorption. At the same time, the NiAl LDH/Biochar is almost stable until the three-cycle adsorption process. The structure of $\mathrm{Ni} / \mathrm{Al} \mathrm{LDH}$ is easily exfoliated during the second and third reuse cycles. Biochar is also unstable toward reuse adsorbent due to the stability of organic materials toward washing and drying. On the other hand, NiAl LDH/Biochar has almost stable reuse adsorbent until the third cycle adsorption process due to small particle formation during NiAl LDH/Biochar synthesis as presented in SEM photos. Thus NiAl $\mathrm{LDH} /$ Biochar in this research is a promising adsorbent for high reusability adsorption of methylene blue. 


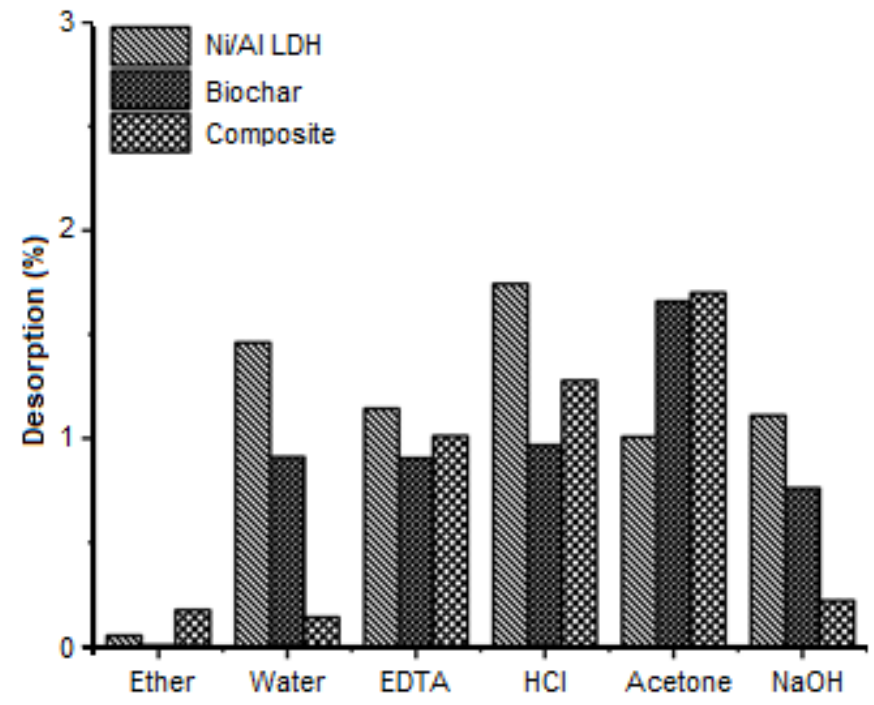

Fig 10. Desorption of methylene blue

\section{- CONCLUSION}

$\mathrm{Ni} / \mathrm{Al}$ LDH-biochar NiAl LDH/Biochar has diffraction at $11.63^{\circ}$ and $22.30^{\circ}$. NiAl LDH/Biochar has the vibration of both biochar and LDH at wavenumber $3441 \mathrm{~cm}^{-1}, 2931 \mathrm{~cm}^{-1}, 2368 \mathrm{~cm}^{-1}, 2283 \mathrm{~cm}^{-1}, 1627 \mathrm{~cm}^{-1}$, $1381 \mathrm{~cm}^{-1}, 1049 \mathrm{~cm}^{-1}$, and $578 \mathrm{~cm}^{-1}$. NiAl LDH/Biochar has more than ten-fold surface area properties $\left(438.942 \mathrm{~m}^{2} / \mathrm{g}\right)$ than biochar $\left(50.936 \mathrm{~m}^{2} / \mathrm{g}\right)$, and $\mathrm{Ni} / \mathrm{Al}$ layered double hydroxide $\left(92.682 \mathrm{~m}^{2} / \mathrm{g}\right)$. Thermal analysis showed that NiAl LDH/Biochar has one endothermic peak and two exothermic peaks related to both starting materials. NiAl LDH/Biochar has a small agglomeration and a more regular form than starting materials. Adsorption of methylene blue on NiAl LDH/Biochar follows the pseudo-second-order kinetic adsorption model and is classified as chemi-physical adsorption. NiAl LDH/Biochar has high reusability properties and can be used as a potential adsorbent to remove methylene blue from an aqueous solution.

\section{- ACKNOWLEDGMENTS}

Authors thank Universitas Sriwijaya for this research's financial support by Hibah Profesi 2020-2021 No. 0687/UN9/SK.BUK.KP/2020 and thank Research Center of Inorganic Materials and Complexes FMIPA Universitas Sriwijaya for analysis instrumentation measurement.

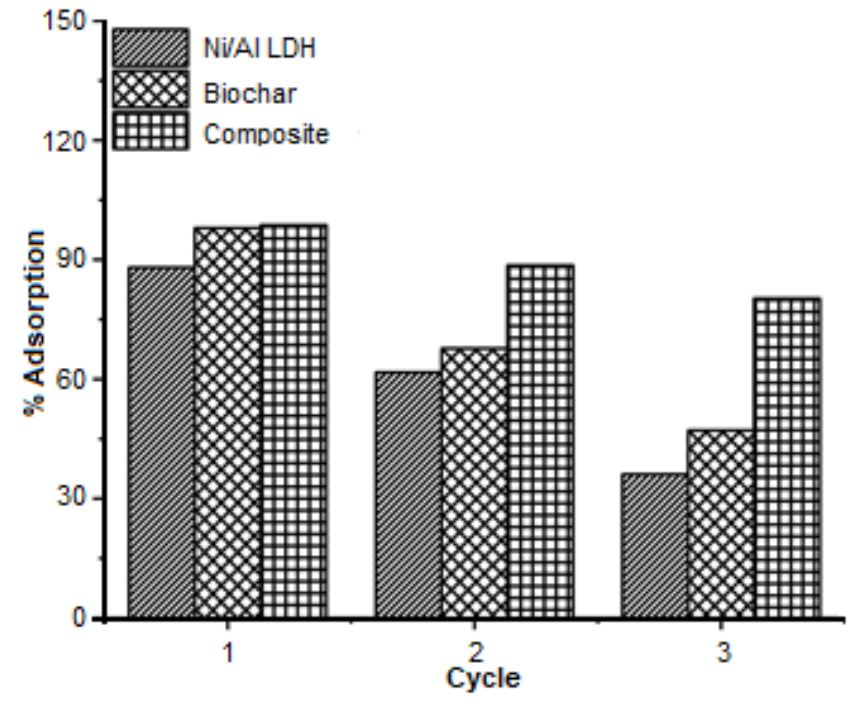

Fig 11. Cycling process of adsorbent

\section{- AUTHOR CONTRIBUTIONS}

NRP and RJS conducted the experiment, collecting and assembling the data; AL wrote the manuscript and concept of the research; TT and $\mathrm{NH}$ analysis, and interpreted the data. All authors agreed to the final version of this manuscript.

\section{- REFERENCES}

[1] Hu, H., Wageh, S., Al-Ghamdi, A.A., Yang, S., Tian, Z., Cheng, B., and Ho, W., 2020, NiFe-LDH nanosheet/carbon fiber nanocomposite with enhanced anionic dye adsorption performance, Appl. Surf. Sci., 511, 145570.

[2] Yaseen, M., Singh, M., and Ram, D., 2014, Growth, yield and economics of vetiver (Vetiveria zizanioides L. Nash) under intercropping system, Ind. Crops Prod., 61, 417-421.

[3] Tezcan Un, U., and Ates, F., 2019, Low-cost adsorbent prepared from poplar sawdust for removal of disperse orange 30 dye from aqueous solutions, Int. J. Environ. Sci. Technol., 16 (2), 899908.

[4] Palapa, N.R., Juleanti, N., Taher, T., and Lesbani, A., 2020, Unique adsorption properties of malachite green on interlayer space of $\mathrm{Cu}-\mathrm{Al}$ and $\mathrm{Cu}-\mathrm{Al}-$ $\mathrm{SiW}_{12} \mathrm{O}_{40}$ layered double hydroxides, Bull. Chem. React. Eng. Catal., 15 (3), 653-661. 
[5] Yan, H., Li, H., Yang, H., Li, A., and Cheng, R., 2013, Removal of various cationic dyes from aqueous solutions using a kind of fully biodegradable magnetic composite microsphere, Chem. Eng. J., 223, 402-411.

[6] Long, Y., Wang, Y., Zhang, D., Ju, P., and Sun, Y., 2016, Facile synthesis of BiOI in hierarchical nanostructure preparation and its photocatalytic application to organic dye removal and biocidal effect of bacteria, J. Colloid Interface Sci., 481, 47-56.

[7] Soleimani, K., Tehrani, A.D., and Adeli, M., 2018, Bioconjugated graphene oxide hydrogel as an effective adsorbent for cationic dyes removal, Ecotoxicol. Environ. Saf., 147, 34-42.

[8] Logita, H.H., Tadesse, A., and Kebede, T., 2015, Synthesis, characterization and photocatalytic activity of $\mathrm{MnO}_{2} / \mathrm{Al}_{2} \mathrm{O}_{3} / \mathrm{Fe}_{2} \mathrm{O}_{3}$ nanocomposite for degradation of malachite green, Afr. J. Pure Appl. Chem., 9 (11), 211-222.

[9] Meili, L., Lins, P.V., Zanta, C.L.P.S., Soletti, J.I., Ribeiro, L.M.O., Dornelas, C.B., Silva, T.L., and Vieira, M.G.A., 2019, MgAl-LDH/Biochar composites for methylene blue removal by adsorption, Appl. Clay Sci., 168, 11-20.

[10] Annadurai, G., Juang, R.S., and Lee, D.J., 2002, Use of cellulose-based wastes for adsorption of dyes from aqueous solutions, J. Hazard. Mater., 92 (3), 263274.

[11] Elmoubarki, R., Mahjoubi, F.Z., Elhalil, A., Tounsadi, H., Abdennouri, M., Sadiq, M., Qourzal, S., Zouhri, A., and Barka, N., 2017, Ni/Fe and Mg/Fe layered double hydroxides and their calcined derivatives: Preparation, characterization and application on textile dyes removal, J. Mater. Res. Technol., 6 (3), 271-283.

[12] Özdemir, M., Durmuş, Ö., Şahin, Ö., and Saka, C., 2016, Removal of methylene blue, methyl violet, rhodamine B, alizarin red, and bromocresol green dyes from aqueous solutions on activated cotton stalks, Desalin. Water Treat., 57 (38), 18038-18048.

[13] Zhang, P., O’Connor, D., Wang, Y., Jiang, L., Xia, T., Wang, L., Tsang, D.C.W., Ok, Y.S., and Hou, D., 2020, A green biochar/iron oxide composite for methylene blue removal, J. Hazard. Mater., 384, 121286.

[14] Kubo, D., Tadanaga, K., Hayashi, A., and Tatsumisago, M., 2012, Hydroxide ion conduction in Ni-Al layered double hydroxide, J. Electroanal. Chem., 671, 102-105.

[15] Oktrianti, M., Palapa, N.R., Mohadi, R., and Lesbani, A., 2020, Effective removal of iron(II) from aqueous solution by adsorption using $\mathrm{Zn} / \mathrm{Cr}$ layered double hydroxides intercalated with Keggin ion, J. Ecol. Eng., 21 (5), 63-71.

[16] Liao, X.J., and Chen, G.S., 2016, A hybrid hydrogel based on clay nanoplatelets and host-guest inclusion complexes, Chin. Chem. Lett., 27 (4), 583-587.

[17] González, M.A., Pavlovic, I., and Barriga, C., 2015, $\mathrm{Cu}(\mathrm{II}), \mathrm{Pb}(\mathrm{II})$ and $\mathrm{Cd}(\mathrm{II})$ sorption on different layered double hydroxides. A kinetic and thermodynamic study and competing factors, Chem. Eng. J., 269, 221-228.

[18] Guo, Y., Zhu, Z., Qiu, Y., and Zhao, J., 2013, Synthesis of mesoporous $\mathrm{Cu} / \mathrm{Mg} / \mathrm{Fe}$ layered double hydroxide and its adsorption performance for arsenate in aqueous solutions, J. Environ. Sci., 25 (5), 944-953.

[19] Kovanda, F., Jindová, E., Lang, K., Kubát, P., and Sedláková, Z., 2010, Preparation of layered double hydroxides intercalated with organic anions and their application in $\mathrm{LDH} /$ poly(butyl methacrylate) nanocomposites, Appl. Clay Sci., 48 (1-2), 260-270.

[20] Liu, Z., and Zhang, F.S., 2009, Removal of lead from water using biochars prepared from hydrothermal liquefaction of biomass, J. Hazard. Mater., 167 (13), 933-939.

[21] Tan, X., Liu, Y., Zeng, G., Wang, X., Hu, X., Gu, Y., and Yang, Z., 2015, Application of biochar for the removal of pollutants from aqueous solutions, Chemosphere, 125, 70-85.

[22] Ahmad, R., and Mondal, P.K., 2010, Application of modified water nut carbon as a sorbent in Congo red and Malachite green dye contaminated wastewater remediation, Sep. Sci. Technol., 45 (3), 394-403.

[23] Wan, S., Wang, S., Li, Y., and Gao, B., 2017, Functionalizing biochar with $\mathrm{Mg}-\mathrm{Al}$ and $\mathrm{Mg}-\mathrm{Fe}$ layered double hydroxides for removal of 
phosphate from aqueous solutions, J. Ind. Eng. Chem., 47, 246-253.

[24] Zhang, M., Gao, B., Yao, Y., and Inyang, M., 2013, Phosphate removal ability of biochar/MgAl-LDH ultra-fine composites prepared by liquid-phase deposition, Chemosphere, 92 (8), 1042-1047.

[25] Zubair, M., Manzar, M.S., Mu'azu, N.D., Anil, I., Blaisi, N.I., and Al-Harthi, M.A., 2020, Functionalized MgAl-layered hydroxide intercalated date-palm biochar for enhanced uptake of cationic dye: Kinetics, isotherm and thermodynamic studies, Appl. Clay Sci., 190, 105587.

[26] Lins, P.V.S., Henrique, D.C., Ide, A.H., da silva Duarte, J.L., Dotto, G.L., Yazidi, A., Sellaoui, L., Erto, A., Zanta, C.L.P.S., and Meili, L., 2020, Adsorption of a non-steroidal anti-inflammatory drug onto $\mathrm{MgAl} / \mathrm{LDH}$-activated carbon composite Experimental investigation and statistical physics modeling, Colloids Surf., A, 586, 124217.

[27] Wang, S., Gao, B., Li, Y., Zimmerman, A.R., and Cao, $\mathrm{X}$., 2016, Sorption of arsenic onto Ni/Fe layered double hydroxide (LDH)-biochar composites, RSC Adv., 6 (22), 17792-17799.

[28] Palapa, N.R., Mohadi, R., and Lesbani, A., 2018, Adsorption of direct yellow dye from aqueous solution by $\mathrm{Ni} / \mathrm{Al}$ and $\mathrm{Zn} / \mathrm{Al}$ layered double hydroxides, AIP Conf. Proc., 2026, 020018.

[29] Bai, Z., Hu, C., Liu, H., and Qu, J., 2019, Selective adsorption of fluoride from drinking water using NiAl-layered metal oxide film electrode, J. Colloid Interface Sci., 539, 146-151.

[30] Tao, X., Han, Y., Sun, C., Huang, L., and Xu, D., 2019, Plasma modification of NiAlCe-LDH as improved photocatalyst for organic dye wastewater degradation, Appl. Clay Sci., 172, 75-79.

[31] Xiao, F., Cheng, J., Cao, W., Yang, C., Chen, J., and Luo, Z., 2019, Removal of heavy metals from aqueous solution using chitosan-combined magnetic biochars, J. Colloid Interface Sci., 540, 579-584.

[32] Xia, Y., Yang, T., Zhu, N., Li, D., Chen, Z., Lang, Q., Liu, Z., and Jiao, W., 2019, Enhanced adsorption of $\mathrm{Pb}(\mathrm{II})$ onto modified hydrochar: Modeling and mechanism analysis, Bioresour. Technol., 288, 121593.

[33] Wang, T., Li, C., Wang, C., and Wang, H., 2018, Biochar/MnAl-LDH composites for $\mathrm{Cu}$ (II) removal from aqueous solution, Colloids Surf., A, 538, 443450.

[34] Shaji, A., and Zachariah, A.K., 2017, "Surface area analysis of nanomaterials, in Micro and Nano Technologies, Thermal and Rheological Measurement Techniques for Nanomaterials Characterization, Volume 3, Eds. Thomas, S., Thomas, R., Zachariah, A.K., and Mishra, R.K., Elsevier Inc., 197-231.

[35] Beakou, B.H., El Hassani, K., Houssaini, M.A., Belbahloul, M., Oukani, E., and Anouar, A., 2017, A novel biochar from Manihot esculenta Crantz waste: Application for the removal of malachite green from wastewater and optimization of the adsorption process, Water Sci. Technol., 76 (6), 1447-1456.

[36] Iftekhar, S., Ramasamy, D.L., Srivastava, V., Asif, M.B., and Sillanpää, M., 2018, Understanding the factors affecting the adsorption of Lanthanum using different adsorbents: A critical review, Chemosphere, 204, 413-430.

[37] Kushwaha, A.K., Gupta, N., and Chattopadhyaya, M.C., 2014, Removal of cationic methylene blue and malachite green dyes from aqueous solution by waste materials of Daucus carota, J. Saudi Chem. Soc., 18 (3), 200-207.

[38] Bulut, E., Özacar, M., and Şengil, İ.A., 2008, Adsorption of malachite green onto bentonite: Equilibrium and kinetic studies and process design, Microporous Mesoporous Mater., 115 (3), 234-246.

[39] Wang, Y., Zhang, Y., Li, S., Zhong, W., and Wei, W., 2018, Enhanced methylene blue adsorption onto activated reed-derived biochar by tannic acid, $J$. Mol. Liq., 268, 658-666.

[40] Peres, E.C., Slaviero, J.C., Cunha, A.M., HosseiniBandegharaei, A., and Dotto, G.L., 2018, Microwave synthesis of silica nanoparticles and its application for methylene blue adsorption, $J$. Environ. Chem. Eng., 6 (1), 649-659. 
[41] Qiao, Y., Li, Q., Chi, H., Li, M., Lv, Y., Feng, S., Zhu, R., and Li, K., 2018, Methyl blue adsorption properties and bacteriostatic activities of $\mathrm{Mg}$-Al layer oxides via a facile preparation method, Appl. Clay Sci., 163, 119-128.

[42] Hasan, R., Ying, W.J., Cheng, C.C., Jaafar, N.F., Jusoh, R., Jalil, A.A., and Setiabudi, H.D., 2020, Methylene blue adsorption onto cockle shells-treated banana pith: Optimization, isotherm, kinetic, and thermodynamic studies, Indones. J. Chem., 20 (2), 368-378.

[43] Aguiar, J.E., Bezerra, B.T.C., Braga, B.M., Lima, D.S., Nogueira, R.E.F.Q., de Lucena, S.M.P., and da Silva, I.J., 2013, Adsorption of anionic and cationic dyes from aqueous solution on non-calcined $\mathrm{Mg}-\mathrm{Al}$ layered double hydroxide: Experimental and theoretical study, Sep. Sci. Technol., 48 (15), 23072316.

[44] Purnaningtyas, M.A.K., Sudiono, S., and Siswanta, D., 2020, Synthesis of activated carbon/chitosan/alginate beads powder as an adsorbent for methylene blue and methyl violet $2 \mathrm{~B}$ dyes, Indones. J. Chem., 20 (5), 1119-1130.

[45] Rao, V.V.B., and Rao, S.R.M., 2006, Adsorption studies on treatment of textile dyeing industrial effluent by fly ash, Chem. Eng. J., 116 (1), 77-84.

[46] Hu, W., Wu, X., Jiao, F., Yang, W., and Zhou, Y., 2016, Preparation and characterization of magnetic $\mathrm{Fe}_{3} \mathrm{O}_{4} @$ sulfonated $\beta$-cyclodextrin intercalated layered double hydroxides for methylene blue removal, Desalin. Water Treat., 57 (53), 2583025841.

[47] Vadivelan, V., and Kumar, K.V., 2005, Equilibrium, kinetics, mechanism, and process design for the sorption of methylene blue onto rice husk, J. Colloid Interface Sci., 286 (1), 90-100.

[48] Yavuz, E., Bayramoğlu, G., Arica, M.Y., and Senkal, B.F., 2011, Preparation of poly (acrylic acid) containing core-shell type resin for removal of basic dyes, J. Chem. Technol. Biotechnol., 86 (5), 699-705.

[49] Lesbani, A., Asri, F., Palapa, N.R., Taher, T., and Rachmat, A., 2020, Efficient removal of methylene blue by adsorption using composite based $\mathrm{Ca} / \mathrm{Al}$ layered double hydroxide-biochar, Global NEST J., 22 (2), 250-257.

[50] Liu, J., Li, X., Luo, J., Duan, C., Hu, H., and Qian, G., 2014, Enhanced decolourisation of methylene blue by LDH-bacteria aggregates with bioregeneration, Chem. Eng. J., 242, 187-194.

[51] Taher, T., Mohadi, R., Rohendi, D., and Lesbani, A., 2017, Kinetic and thermodynamic adsorption studies of Congo red on bentonite, AIP Conf. Proc., 1823, 020028.

[52] Mahmoodi, N.M., Hayati, B., Arami, M., and Lan, C., 2011, Adsorption of textile dyes on Pine Cone from colored wastewater: Kinetic, equilibrium and thermodynamic studies, Desalination, 268 (1-3), 117-125. 